\title{
Study of Struvite Crystal Growth with The Addition of Tartaric Acid
}

\author{
Dyah Suci Perwitasari ${ }^{1 *}$, Sintha Soraya Santi ${ }^{1}$, Stefanus Muryanto ${ }^{2}$, Jamari J ${ }^{3}$, Bayuseno AP ${ }^{3}$ \\ ${ }^{1}$ Departemen of Chemical Enginering UPN "Veteran"Jawa Timur, Surabaya, East Java, Indonesia \\ ${ }^{2}$ Departemen of Chemical Enginering UNTAG University in Semarang, Indonesia \\ ${ }^{3}$ Departemen of Mechanical Enginering Diponegoro University Tembalang Campus, Semarang 50275, Indonesia
}

\begin{abstract}
The purpose of this study was to study the growth of struvite crystals from the effect of adding tartaric acid additives to an aqueous solution containing $\mathrm{Mg}^{2+}, \mathrm{NH}_{4}{ }^{+}$, and $\mathrm{PO}_{4}{ }^{3-}$ with a molar ratio of 1:1:1. The results of the study, it was found that the more the concentration of tartaric acid additive was added, it got smaller the rate constant was. By decreasing the value of the constant rate, the growth of struvite crystals also decreased then the growth of struvite crystals became inhibited. On the other hand, struvite has the potential to be used as a fertilizer. The concentration of tartaric acid also had a significant effect on controlling the production of struvite. The optimum crystal mass was obtained at a concentration of $20 \mathrm{ppm}$ tartaric acid, a temperature of $40^{\circ} \mathrm{C}$ and a stirrer rotation of $300 \mathrm{rpm}$ so that it can be applied in manufacture industry of struvite fertilizer.
\end{abstract}

Keywords: Struvite Crystals, Tartaric Acid,

\section{Introduction}

Struvite is the crystal of magnesium, ammonium, and phosphate. The process of forming struvite is carried out by reacting $\mathrm{Mg}^{2+}, \mathrm{NH}_{4}{ }^{+}$, and $\mathrm{PO}_{4}{ }^{3-}$. This crystal has the chemical formula, magnesium ammonium phosphate hexahydrate $\left(\mathrm{MgNH}_{4} \mathrm{PO}_{4} \cdot 6 \mathrm{H}_{2} \mathrm{O}\right)$, and generally it is a white crystal. In an aqueous solution containing $\mathrm{Mg}^{2+}$, $\mathrm{NH}_{4}{ }^{+}$, and $\mathrm{PO}_{4}{ }^{3-}$ in equivalent amounts in a 1:1:1 molar ratio, struvite crystallization can occur spontaneously under the influence of temperature, $\mathrm{pH}$, concentration and stirring. Struvite crystals are minerals commonly found in pipes, pumps and other industrial equipment $[1$, 2 ]. The process of formation of struvite was two steps, namely nucleation and growth. The former step occurs when the constituent ions combine to form a crystal nucleus. The formation of crystal nucleus was formed when the concentration of magnesium, ammonium, and phosphate exceeds the solubility of the resulting product which were the value of Ksp (solubility product constant). The value of Ksp for struvite ranged from 5.5 $\mathrm{x} 10^{-14}$ to $2.51 \times 10^{-13}$. Struvite itself contains phosphate which can be used as fertilizer. [1]. The crystallization of struvite is influenced by several factors including $\mathrm{pH}$, temperature, stirring cycle and additives. $\mathrm{pH}$ is an important factor in the formation of struvite crystals because it affects the solubility and thermodynamic properties [3]. To reduce struvite crystals as crystalline scales in general use inorganic additives $\mathrm{Cu}^{2+}$ and $\mathrm{Zn}^{2+}$ $[4,5], \mathrm{Cu}^{2+}, \mathrm{Pb}^{2+}$ and $\mathrm{Zn}^{2+}$ [6] or organic additives malic acid [7], carboxylic acid compounds [8], citric acid [9], maleic acid [10] which can inhibit the growth of struvite crystals. In previous studies, three carboxylic acids (citric acid, tartaric acid and maleic acid) were used as effective inhibitors even at low molar concentrations [8]. The additive used in this research is tartaric acid which is a carboxylic acid, which is a weak organic acid that is environmentally friendly and effective at low concentrations. The purpose of this study was to study the growth of struvite crystals from the effect of adding tartaric acid additives to an aqueous solution containing $\mathrm{Mg}^{2+}, \mathrm{NH}_{4}{ }^{+}$, and $\mathrm{PO}_{4}{ }^{3-}$ with a molar ratio of $1: 1: 1$.

\section{Materials and Methods}

\subsection{Chemicals}

Materials were $\mathrm{MgCl}_{2} \cdot 6 \mathrm{H}_{2} \mathrm{O}$ and $\mathrm{NH}_{4} \mathrm{H}_{2} \mathrm{PO}_{4}$ with analytical grade chemicals (MerckTM). The Tartaric Acid $\left(\mathrm{C}_{4} \mathrm{H}_{6} \mathrm{O}_{6}\right)$ with analitycal grade chemicals (MerckTM). was also used as additives. Here $250 \mathrm{ml} \mathrm{0,1}$ $\mathrm{M}$ which contained $\mathrm{MgCl}_{2} .6 \mathrm{H}_{2} \mathrm{O}$ and $\mathrm{NH}_{4} \mathrm{H}_{2} \mathrm{PO}_{4}$ were prepare. In addition, a $\mathrm{pH} 9$ solution was prepared by diluting $1 \mathrm{~N}$. KOH. Solution. In this work, the effect of temperature $40^{\circ} \mathrm{C}$, stirring speed $300 \mathrm{rpm}$, and tartaric acid concentration $0 ; 1 ; 10$, and $20 \mathrm{ppm}$ was evaluated. The slurry obtained was separated through filter paper, while the sample obtained was dried at room temperature and then weighed using a sartorius scale.

\subsection{SEM-EDX and XRPD method}

The particles size and morphology were analysed by SEM (scanning electron microscopy) and EDX (energy dispersive X-ray spectroscopy). Measurements on the SEM images were made with J-image software. For EDX analysis, the samples were coated in a thin-film of gold.

\footnotetext{
* Corresponding author : saridyah05@gmail.com
} 
Sample identification was done by XRPD (X-ray powder diffraction) analysis. In this method, the position of the highest peak is verified. The mineral phase was identified according to the Rietveld's way using Fullprof-2k, software, program version 3.30 [11].

\section{Results and Discussion}

Figure 1 shows a decrease in $\mathrm{pH}$ without the addition of tartaric acid and with the addition of tartaric acid. As seen, the $\mathrm{pH}$ dropped sharply in the first five minutes, followed by a gradual decrease until it stabilized and the decline ended after 60 minutes. As reviewed by BabicIvancic et al. [12], the decrease in $\mathrm{pH}$ then stabilized, indicating that struvite crystals were formed. The change in $\mathrm{pH}$ resulting from the crystallization reaction with the release of $\mathrm{H}^{+}$ions is caused by the hydrolysis of tartaric acid (organic acids) it is a weak acid, with very low Ksp. Crystallization of struvite follows two main mechanisms, namely nucleation and crystal growth [13]. The time required for the formation of the first crystal nucleus is referred to as the induction time. The crystal growth rate is characterized by an increase in crystal mass, called the overall growth rate and does not pay attention to the growth on the crystal surface [14]. The process of struvite crystallization occurs by releasing $\mathrm{H}^{+}$ions and followed by a reduction of $\mathrm{Mg}^{2+}$, thereby decreasing the $\mathrm{pH}$ solution. Thus, the crystallization rate was obtained by measuring the accretion in $[\mathrm{H}+]$ as evidenced by a decrease in $\mathrm{pH}$. The crystallization process was investigated according to the $\mathrm{pH}$ data measuring to calculate the reduction in $\mathrm{Mg} 2+$, as previously reported by Muryanto and Bayuseno [4]. In that study, they mentioned that the decline of $\mathrm{pH}$ was related to the initial concentration of the magnesium, in which struvite crystals first formed at the rate of crystallization of struvite.

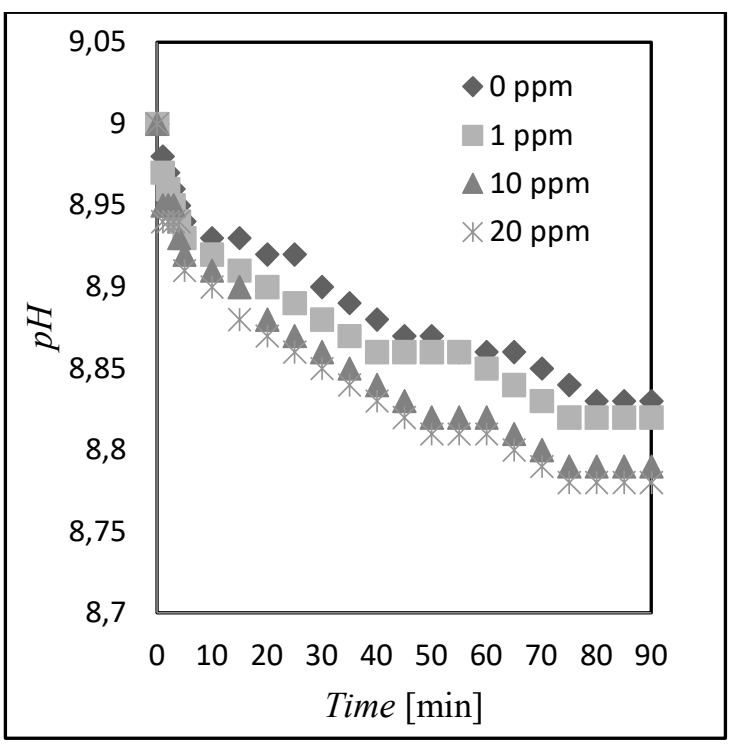

Fig. 1. $\mathrm{pH}$ in the presence tartaric acid concentration 0 ; $1 ; 10 ; 20 \mathrm{ppm}$ at $40^{\circ} \mathrm{C}, 300 \mathrm{rpm}$.
The higher the concentration of tartaric acid additive added, the smaller the rate constant. By decreasing the value of the constant rate, the growth of struvite crystals also decreases so that the growth of struvite crystals becomes inhibited. On the other hand, struvite has the potential to be used as a fertilizer [1]. As shown in table 1.

Table 1 . The rate constants crystallization of at $40^{\circ} \mathrm{C}$.

\begin{tabular}{|l|l|l|l|}
\hline ppm & Regression equation (y) & $\begin{array}{l}\text { Rate } \\
\text { constant }\end{array}$ & $\mathrm{R}^{2}$ \\
\hline 0 & $-0.0269 \mathrm{x}-3.3253$ & 1.614 & 0.9611 \\
1 & $-0.0241 \mathrm{x}-3.4890$ & 1.446 & 0.9608 \\
10 & $-0.0205 \mathrm{x}-3.2913$ & 1.230 & 0.9679 \\
20 & $-0.0169 \mathrm{x}-3.3904$ & 1.014 & 0.9430 \\
\hline
\end{tabular}

The Characteristics of Struvite

Crystals were observed using SEM-EDX and XRPD at optimum conditions with a temperature of $40^{\circ} \mathrm{C}, 300$ rpm stirrer rotation and $20 \mathrm{ppm}$ tartaric acid concentration. The above conditions have been calculated using the Response Surface Methodology (RSM) method with the optimal crystal mass response value of 10,483 $\mathrm{mg}$ [15]. SEM-EDX and XRD images at optimum conditions are shown in the figure below.

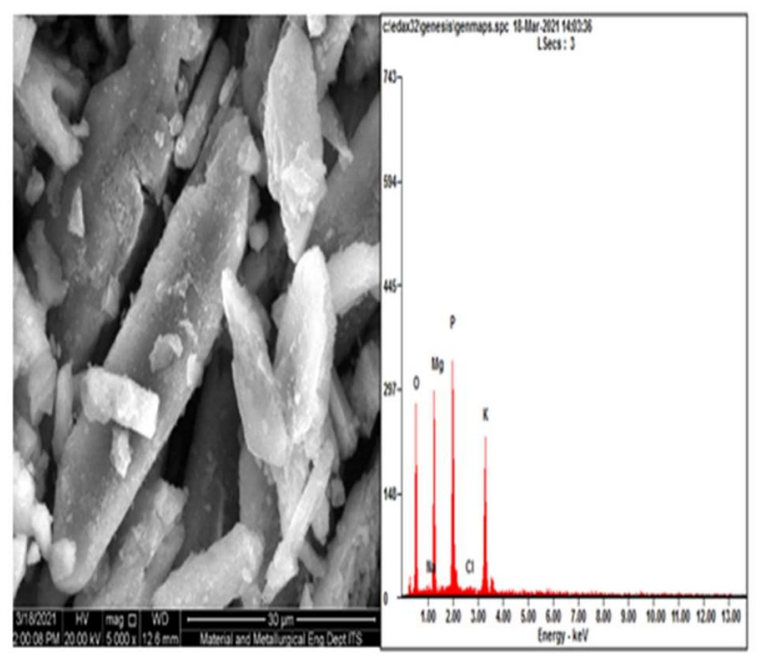

Fig.2. SEM image and EDX at $300 \mathrm{rpm}, 40^{\circ} \mathrm{C}, 20 \mathrm{ppm}$.

The crystal form was analyzed using SEM-EDX, where pure struvite crystals will be rod-shaped with pointed ends and surfaces intact without defects. [16]. With the addition of $20 \mathrm{ppm}$ tartaric acid additive, the struvite crystal form looks incomplete with defects as shown in Figure 2. 


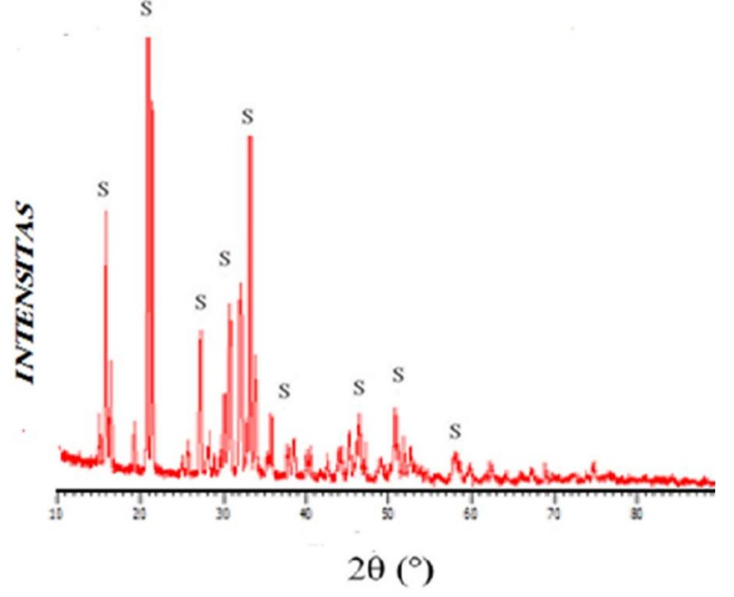

Fig.3. XRPD patterns of precipitate at tartaric acid concentration $20 \mathrm{ppm}$. The peaks are labelled $\mathrm{S}$ (struvite).

XRPD analysis was used to determine the struvite obtained in the form of crystals by showing the peak pattern on the XRPD results. As in figure 3.

\section{Conclusions}

The results of the study, it was found that the more the concentration of tartaric acid additives added, the smaller the constant level. With a decrease in the constant value, the growth of struvite crystals also decreases so that the growth of struvite crystals becomes inhibited. On the other hand, struvite has the potential to be used as a fertilizer. The concentration of tartaric acid also had a significant effect on controlling the production of struvite. The optimum crystal mass was obtained at a concentration of $20 \mathrm{ppm}$ tartaric acid, a temperature of $40^{\circ} \mathrm{C}$ and a stirrer rotation of $300 \mathrm{rpm}$ so that it can be applied in industry in the manufacture of struvite fertilizer

Ack to the directorate of resources, directorate general of higher education, ministry of education, culture, research and technology in accordance with the multiyear research contract for the superior basic research program of higher education number: $02 / \mathrm{UN} 63.8 / \mathrm{LT}$ Kontrak/VII/2021

\section{References}

1. J.D Doyle., S.A Parsons, Struvite formation, control and recovery, Water Research, 36, 3925 3940, (2002).

2. A Capdevielle, E Sykorová., B Biscans, Optimization of struvite precipitation in synthetic biologically treated swine wastewaterDetermination of the optimal process parameters, Journal of Hazardous Materials, 244-245, 357 369, 2013.

3. M Ronteltap., M Maurer., W Gujer. Struvite precipitation thermodynamics insource- separatedurine, Water Research, 41, 977 - 984, (2007).

4. S Muryanto., A.P Bayuseno. Influence of $\mathrm{Cu} 2+$ and $\mathrm{Zn} 2+$ as additives on crystallization kinetics andmorphology of struvite, Powder Technology, 253, $602-607,(2014)$.

5. A.A Rouff, M.V Ramlogan., A Rabinovich. Synergistic Removal of Zinc and Copper in Greenhouse Waste Effluent by Struvite. ACS Sustainable Chemistry and Engineering, 4, 1319 1327, (2016).

6. D.S Perwitasari., S Muryanto., J Jamari., A.P Bayuseno. Kinetics and morphology analysis of struvite precipitated from aqueous solution under the influence of heavy metals: $\mathrm{Cu}^{2+}, \mathrm{Pb}^{2+}, \mathrm{Zn}^{2+}$, Journal of Environmental Chemical Engineering, 6, 1, $37-43$, (2018).

7. Makmun, Hisyam, AP Bayuseno, S Muryanto, Pembentukan kerak kalsium karbonat dan penambahan aditif asam malat, Prosiding Seminar Nasional Sains Dan Teknologi Fakultas Teknik vol ,1, No 1, (2013).

8. T Rabizadeh., C.L Peacock and L.G Benning. Carboxylic acids: effective inhibitors for calcium sulfate precipitation, Mineralogical Magazine, 78, 6, 1465 - 1472, (2014).

9. D.S Perwitasari., L Edahwati., S Sutiyono., S Muryanto., J Jamari., A.P Bayuseno. Phosphate recovery through struvite-family crystals precipitated in the presence of citric acid: mineralogical phase and morphology evaluation, Environmental Technology, 38, 22, 2844 - 2855. (2017).

10. D.S Perwitasari., S Muryanto., J Jamari., A.P Bayuseno. A.P. Modelling and optimization of struvite crystal scaling using experimental design methodology for maleic acid, Atlantis Highlights in Engineering (AHE), 1,253-258, (2018).

11. H.M Rietveld. A profile refinement method for nuclear and magnetic structures, Journal of Applied Crystallography, 2, 65 - 71, (1969)

12. V Babic-Ivančic, J Kontrec., L Brečevic, Kinetics of struvite to newberyite transformation in the precipitation system $\mathrm{MgCl} 2-\mathrm{NH} 4 \mathrm{H} 2 \mathrm{PO} 4-\mathrm{NaOH}-$ H2O, Water Research, 40, 3447 - 3455, (2006)

13. J Prywer., M Olszynski. Influence of disodium EDTA on the nucleation and growth of struvite and carbonate apatite, Journal of Crystal Growth, 37, 108 - 114, (2013).

14. A.S Myerson. Handbook of industrial crystallization, Woburn (USA), ButterworthHeinemann, (2002)

15. D.S Perwitasari, S.S Santi, A Muhammad, A Yahya, Optimization Of Struvite Crystallization with addition of tataric acid in liquid waste as fertilizer materials, Jour of adv research in dynamical \& control systems, 12,02,1802-1806, (2020). 
16. A.R Fitriana dan I. Warmadewanthi. Penurunan kadar amonium dan fosfat pada limbah cair industri pupuk. Jurnal Teknik ITS. 5(2), (2016). 